\title{
Somatic Cell and Cheesemaking Variables of WAD Goat Milk: Influence of Parity and Lactation Stage
}

\author{
A. T. Yusuff*, A. A. Badmos, E. V. Awofadeju, A. A. Akintunde, O. I. Alli, V. O. Chimezie, \& \\ T. R. Fayeye \\ Department of Animal Production, University of Ilorin, \\ P.M.B. 1515, Ilorin, Nigeria \\ *Corresponding author: yusuff.at@unilorin.edu.ng \\ (Received 14-12-2020; Revised 29-03-2021; Accepted 13-04-2021)
}

\begin{abstract}
The suitability of any goat breed for dairy purposes depends on its assessment of milk-related traits. This study evaluates the influence of parity and lactation stage on somatic cell count (SCC) and cheese-making variables of West African Dwarf (WAD) goat milk. A total of 48 lactating WAD does of three different parities (the $1^{\text {st }}, 2^{\text {nd }}$, and $3^{\text {rd }}$ ) were milked over a period of time-phased into three stages of lactation (early, mid, and late). The milk was subjected to SCC and cheese-making during which coagulation time, cheese yield (CY), whey volume, and whey $\mathrm{pH}$ were recorded. Collected data were subjected to analysis of variance and Pearsons' correlation. The result revealed that the milk SCC of the does in the $3^{\text {rd }}$ parity $\left(2.16 \times 10^{5}\right.$ cells $)$ was significantly $(\mathrm{p}<0.05)$ higher than $1.89 \times 10^{5}$ and $1.87 \times 10^{5}$ cells in the milk of the $1^{\text {st }}$ and the $2^{\text {nd }}$ parity does respectively. There was a similar variation trend of SCC as lactation progresses in each of the parities. The CY significantly increased $(\mathrm{p}<0.05)$ as lactation progresses in the $1^{\text {st }}$ parity (early $-16.95 \%$; mid $-17.21 \%$; late $-20.85 \%$ ) while, the milk of the $2^{\text {nd }}$ and the $3^{\text {rd }}$ parity from mid to late lactation stage yielded statistically similar cheese that was comparable with late lactation $\mathrm{CY}$ of the $1^{\text {st }}$ parity does. The lactation stage and SCC were positively correlated with $\mathrm{CY}$. The volume and $\mathrm{pH}$ of the whey were neither affected by the lactation stage nor parity. The study concludes that parity uncovers the effect of lactation stage on the milk SCC of WAD does while the milk obtained from mid to late lactation stage yields more cheese.
\end{abstract}

Keywords: goat milk; lactation; parity; somatic cell; cheese

\section{INTRODUCTION}

Developing countries are endowed with numerous but underutilized animal resources, including goats. The West African Dwarf (WAD) goat is a prominent breed that is highly reputed for its hardiness and high kidding rate (Abdul-Rahman, 2017). This breed is believed to have disease resistance which makes it thrive in places where other breeds would only manage to survive (Chiejina \& Behnke, 2011; Yusuff \& Fayeye, 2016). FAOSTAT (2018) report indicated Nigeria's goats to be about 79 million, with WAD constituting the secondlargest breed. This invariably implies a potential economic prospect if this breed is commercially harnessed for dairy purposes.

Goat is globally kept for several purposes, among which milk cannot be undermined. However, the WAD goat is rarely milked for human consumption despite the nutritional benefits and the value chain accruable from this renewable product (Turkmen, 2017; Clark \& Mora-Garcia, 2017). This breed of goat has a relatively low daily milk yield, ranging from $0.18 \mathrm{~L}$ to less than $0.5 \mathrm{~L}$ depending on some factors, while its average lactation duration, which is usually influenced by management practice, falls within the range of 120-130 days (Williams et al., 2019). Increasing urbanization in Nigeria and the consequential changes in the citizen lifestyle towards matching improve in cash income has led to the increased demand for milk and milk products. A recent report by FAO (2019) indicated that dairy products importation to Nigeria accounted for $6 \%$ of the total food import bill, which amounts to an annual expenditure of about US $\$ 480$ million. This shows that there is an affinity for milk products in Nigeria. Similarly, the annual consumption of milk in Nigeria was estimated to be 1.3 billion tonnes which are far higher than the fluctuating production level of about 0.6 million tonnes majorly obtained from cattle (FAO, 2018). Record has indicated that Nigeria's milk importation amounts to \$1.21.5 billion. Hence, it reaffirms a shortage of internally produced milk supply, making it imperative to consider alternative sources of this animal product (Economic Confidential, 2019).

Goat is highly promising in bridging the shortage of milk in Nigeria because of its relative abundance over other ruminant species from which milk can be obtained. The acceptability and paucity of data on the quality of goat milk for human consumption are closely 
related to poor consumer awareness of the product. Generally, information on WAD goat milk's somatic cell count (SCC) and cheese-related properties are scanty. The SCC is an indicator of the health status of the mammary gland, which is the milk secretion apparatus in animals (Petzer et al., 2017). The safety of milk for consumption is often judged using SCC in some advanced climes, while it is most often used in the grading of milk in some countries (Alhussien \& Dang, 2018). One of the major issues in dairy goat farming over the past few decades is SCC, a key indicator in consumer safety and public health. A legal standard is set for milk somatic cell count by some countries but with a wide difference among countries that give it a priority (Petzer et al., 2017). Goat milk of Grade A in the USA, for instance, does not exceed SCC of $1.0 \times 10^{6} / \mathrm{mL}$ ( $\mathrm{Li}$ et al., 2014). Taufik et al. (2011) also reported strict adherence to minimum microbiological characteristics as one of the conditions prior to payment for quality goat milk. Meanwhile, variation in the magnitude of SCC is inevitable and may be influenced by breed, stages of lactation, degree of mammary infections, milking frequency, milking, and post-milking management, and so on (Sharma et al., 2011). The extent to which some of these factors affect SCC of WAD goat milk is yet unknown, though some authors agreed that SCC in goat milk is typically high compared to cow milk (Persson \& Olofsson, 2011; Souza et al., 2012).

A variety of dairy products are available worldwide, but cheese is of more recognition than other dairy foods in developing as well as developed nations (IDF, 2011). People that are indisposed to milk in raw or fairly processed forms find cheese more acceptable, particularly in Nigeria. However, it is noteworthy that some key cheese-related parameters are relevant for the acceptability and sustainability of utilizing WAD goat milk for cheese. An increase in cheese yield, for instance, has been reported to be beneficial to the cheese maker, and was regarded as the most significant economic trait in the dairy industry (Abd El-Gawad \& Ahmed, 2011). Cows were reported to exhibit certain levels of genetic variability in cheese yield (Bittante et al., 2013; Abeykoon et al., 2016), which infers uncertainty of similar cheese yield within a specific breed of goat. A reduction in the time interval during milk processing to cheese is of an advantage in cheese-making plants, particularly when quality is not affected (Cipolat-Gotet et al., 2012). Thus, milk curdling time becomes an important parameter to cheese makers. Although, variability in curdling duration during cheese processing with respect to rennet type has been reported for milk (Pazzola, 2019), and which may also exhibit completely different trends in WAD goat milk. The significance of sensory appraisal on cheese quality has also been extensively demonstrated (Bittante et al., 2011; Sa'nchez-Mac1'asa et al., 2012). However, limited information is available on the evaluation of WAD goats' cheese. Different trends of associations were also reported between various milk properties and cheese yield of some species of milkproducing animals. For instance, a marked decrease in cheese yield was reportedly obtained from goat milk exhibiting high SCC (Silva et al., 2012), while some other authors reported that cheese yield was not affected by SCC (Chen et al., 2010). The information on the extent to which milk and cheese factors are interrelated in WAD goats is also rare. Thus, the thrust of the study was to consider the influence of parity and lactation stage on the somatic cell count and cheese-related parameters of WAD goat milk.

\section{MATERIALS AND METHODS}

\section{Experimental Site}

The experiment was carried out in the small ruminant unit of Teaching and Research Farm, University of Ilorin, Nigeria.

\section{Experimental Goats and Their Management}

A total of 48 apparently healthy lactating WAD does in their $1^{\text {st }}, 2^{\text {nd }}$, and $3^{\text {rd }}$ parities $(n=16$ does per parity) were used for the experiment. Details of the kidding intervals of the does were presented in Table 1. The goats were subjected to similar dietary treatment (Table 2 ). The feed (concentrate) was composed to satisfy the nutrient requirement of lactating goats (NRC, 2007) and was fed ad-libitum throughout the period of the experiment. The experiment spanned for a period of 18 weeks which was phased into three stages of lactation (early stage: 1-6 weeks; mid-stage: 7-12 weeks; late-stage: 13-18 weeks).

\section{Milking of Experimental Animals}

The does were restrained for milking using individual milking stands. The milking process conformed to the guidelines of the Ethical Review Committee of University of Ilorin, Nigeria, with Approval Number:

Table 1. Number of experimental does and their kidding intervals

\begin{tabular}{cccc}
\hline \multirow{2}{*}{ Parity of does } & \multicolumn{3}{c}{ Kidding interval } \\
\cline { 2 - 4 } & $0-7$ days & $8-14$ days & $15-21$ days \\
\hline $1^{\text {st }}$ & 10 & 4 & 2 \\
$2^{\text {nd }}$ & 8 & 6 & 2 \\
$3^{\text {rd }}$ & 9 & 4 & 3 \\
\hline
\end{tabular}

Table 2. Composition of diets fed to experimental goats

\begin{tabular}{lc}
\hline Feed ingredient & Percentage (\%) \\
\hline Wheat bran & 25 \\
Palm kernel cake & 15 \\
Groundnut cake & 5 \\
Rice bran & 5 \\
Corn bran & 10.5 \\
Maize & 20 \\
Cassava peel & 19 \\
Salt & 0.5 \\
Estimated total digestible nutrient (TDN) & 59.09 \\
Estimated crude protein $(\mathrm{CP})$ & 12.23 \\
\hline
\end{tabular}


UERC/ASN/2020/2039. All the necessary pre-milking, milking, and early post milking management procedures were strictly adhered to as reported by Hurst (2014). The milking of the does was done using a handheld milking machine between the hours of 7.00 am and 9.00 am for 18 weeks starting from 5 days post-partum of the does.

\section{Handling of Milk Prior to Analysis}

Properly labeled sterile sample bottles were used, immediately after milking, to keep $10 \mathrm{~mL}$ of milk from each doe for somatic cell count, which was carried out at intervals of seven days. The remaining milk from each class of does (similar parity) was pooled immediately after collection to produce cheese at weekly intervals for a period of 18 weeks.

\section{Cheese Production}

Two liters $(2,000 \mathrm{~mL})$ of pooled raw milk from the goats in the same parity was used once weekly for cheese production. Pooled raw milk of each parity class was further subjected to a cheese-making process in quadruplicate (i.e., $500 \mathrm{~mL} /$ replicate) inside an environmentally controlled laboratory with a constant temperature of $22-23^{\circ} \mathrm{C}$. Extract of Calotropis procera leaf was used as a curdling agent for the raw milk in the process of cheese-making for the experiment. Calotropis procera is a latex-producing plant whose extract has a multitude of proteases that can facilitate milk clotting like conventional bovine rennets during cheese production (Anusha et al., 2014). Extract of Calotropis procera leaves conventionally used in Africa for cheese production was reported to be of high proteolytic capacity in milk curdling (Dubey \& Jagannadham, 2003). The leaves, after being harvested, were washed with sterile water, sliced, and pounded with laboratory mortar and pestle before being sieved to obtain its extract. Concentrated Calotropis procera leaf extract for each day of cheese making was prepared in lots while its proper stirring was ensured before being used as a curdling agent. An equal volume of the extract $(35 \mathrm{~mL})$ was added to each of the $500 \mathrm{~mL}$ pooled milk and gently stirred for 30 seconds. The extract-added milk in different volumetric flasks was gently poured into stainless pots which were later placed on uniformly regulated gas burners of similar flame release. The gas burner was put off immediately after the complete curdling of the milk. The cheese was carefully separated from the whey using filtration techniques.

\section{Data Collection, Experimental Design, and Analysis}

Cheese. The parameters considered during cheese production included cheese clotting duration (CCT) in seconds, cheese yield (CY) in \%, whey volume (WV) in $\mathrm{mL}$, and whey $\mathrm{pH}$. The CCT was the time interval between the ignition of the burner on which the pot containing the milk was placed and the time when complete curdling of the milk was observed. The whey volume was the volumetric reading of the filtrate after the separation of cheese. Cheese yield was the percentage proportion of residue (cheese weight) to the milk weight. The weight of the cheese and that of the milk were measured using an electronic digital scale. The $\mathrm{pH}$ of the whey was determined using a digital $\mathrm{pH}$ meter.

Somatic cell count. Collected milk samples for somatic cell count were subjected to the direct microscopic counting method. To avoid cell death, the milk sample was placed in a water bath maintained at $37^{\circ} \mathrm{C}$ (goat body temperature equivalent). A gentle shaking (10 cycles in 7 seconds in a 1 feet movement) of the milk samples and its use within 30 seconds was ensured to avoid sedimentation or uneven distribution of the somatic cells. Each assay of SCC involved the use 50 $\mu \mathrm{L}$ milk sample, which was dropped on a clean slide using a micropipette, and after which another clean grease-free slide was used to smear the milk droplet on the earlier slide placed on a level surface. The smeared slide was air-dried for 30 minutes before submerging in methylene blue stain for 5 minutes. This was followed by clamping and focusing the air-dried smeared slide with the oil immersion lens of a light microscope (Model: Jiangnan BM-1000 Binocular Biological Series, No:10010072978, rating 100-240V, 50/60Hz, 0.8A, Lamp $\mathrm{S}$ led)) adjusted to provide maximal optical resolution for the counting of visible cells with the nucleus. Neubauer improved cell counting chamber was used to aid SCC. The number of somatic cells per milk sample was measured in cells/mL.

Experimental design and data analysis. The experiment was laid out in a $3 \times 3$ factorial arrangement of completely randomized design. Parity and stages of lactation were considered as the factor, while the levels were defined as the $1^{\text {st }}, 2^{\text {nd, }}$ and $3^{\text {rd }}$ parturitions for parity and; early, mid and late milking periods for stages of lactation. Each parity group comprising of 16 lactating does was randomly segregated into 4 housing replicates for the experiment (4 lactating does per replicate per parity). Collected data were subjected to analysis of variance using the general linear model of MINITAB (2013) statistical package version 13, while the posthoc tests were done using Tukey. Correlation analysis was also conducted to examine the relationship between the cheese yield and various potential predictors.

\section{RESULTS}

The main effects of parity and lactation stage on SCC and cheese variables of WAD goat milk are presented in Table 3. The lactation stage of the goats used for the present study did not influence the SCC of their milk. Milk produced by the goats at different parities showed significant difference $(p<0.05)$ in its SCC, with the goats in the $3^{\text {rd }}$ parity exhibiting a higher SCC $(2.16$ $\left.\mathrm{x} 10^{5} \mathrm{cells} / \mathrm{mL}\right)$ than both the $1^{\text {st }}$ and $2^{\text {nd }}$ parity goats which had $1.87 \times 10^{5}$ and $1.89 \times 10^{5}$ cells/mL respectively. Irrespective of lactation stage and parity, cheese coagulating time and whey $\mathrm{pH}$ were not significantly affected among other cheese variables. The stage of lactation significantly influenced $(\mathrm{p}<0.5)$ cheese yield and whey 
volume in an opposite trend. The CY of the milk produced at the late lactation stage was significantly higher $(p<0.05)$ than that of the mid-lactation stage, which was also higher than the $\mathrm{CY}$ of the milk collected during the early lactation stage. The whey volume declines as lactation progresses across the three parities. The interaction between lactation stage and parity was significant $(\mathrm{p}<0.05)$ for SCC, CY, and WV.

The details of the interaction between parity and lactation stage on the SCC, cheese yield, and whey volume are presented in Table 4. The milk SCC of the does at the first parity declines as lactation progresses, but the milk produced during the late lactation stage had a significantly lower SCC than the early stage. The milk of the does in their second parity had a relatively stable and lower SCC compared to both parities 1 and 3, which had more staggered and higher SCC. Cheese yield significantly ascends as lactation progresses regardless of parity. The CY of the milk produced during the early stage of lactation manifested significant differences among the studied parities with the milk from does in higher parity exhibiting significantly higher CY. No significant difference was observed in the CY of the milk produced at the late stage of lactation among parities while at mid-lactation stage, $\mathrm{CY}$ of the milk of multiparous (the $2^{\text {nd }}$ and $3^{\text {rd }}$ parity) WAD does were comparable but significantly higher than that of primiparous (the $1^{\text {st }}$ parity) does. The volume of the whey decreases as lactation progresses across the three parities, which also showed a relatively similar WV for each stage of lactation.
The relationship between somatic cell count, parity, lactation stage, and cheese-related parameters of WAD goat milk is presented in Table 5. The two independent variables (parity and lactation stage) included in the evaluation behaved differently with respect to their associations with other evaluated parameters. The lactation stage of the goats exhibited highly positive correlations with SCC and CY ( $\mathrm{r}=0.932$ and 0.972 , respectively), while parity had no significant association with all the studied parameters. The lactation stage and whey volume also had a significant but negative association $(r=-0.986)$. On the other hand, parity had no significant relationship with SCC and all the cheese-related parameters. The milk pH and CCT also manifested an association trend similar to parity with other parameters. The SCC of WAD goat milk also manifests a positive correlation with CY ( $(=0.901)$, while the whey volume and SCC were negatively correlated $(\mathrm{r}=-0.908)$.

\section{DISCUSSION}

Somatic cell count in milk has been indicated as a parameter that can be influenced by several factors ranging from intrinsic to extrinsic categories. The former class is animal dependent and may include breed, lactation stage, prolificacy, parity, and milking intervals, while the latter includes milking technicalities, food, season, and other non-animal related components (Shivairo et al., 2013; Jimenez-Granado et al., 2014; Alhussien \& Dang, 2018). An association has also been indicated to exist between mammary bacterial infections

Table 3. The mean of somatic cell count and cheese variables of West African Dwarf goat milk at different parities and lactation stages

\begin{tabular}{|c|c|c|c|c|c|c|}
\hline Factors & Levels & $\begin{array}{c}\text { SCC } \\
\left(\times 10^{5} \text { cells } / \mathrm{mL}\right)\end{array}$ & CCT (s) & $\mathrm{WV}(\mathrm{mL})$ & CY (\%) & $\mathrm{WpH}$ \\
\hline \multirow[t]{5}{*}{ Parity } & $1^{\text {st }}$ & $1.89^{\mathrm{b}}$ & 720.00 & $68.00^{\mathrm{a}}$ & $17.65^{\mathrm{b}}$ & 6.50 \\
\hline & $2^{\text {nd }}$ & $1.87^{\mathrm{b}}$ & 735.00 & $56.00^{\mathrm{b}}$ & $21.78^{\mathrm{a}}$ & 6.80 \\
\hline & $3^{\text {rd }}$ & $2.16^{\mathrm{a}}$ & 738.00 & $54.00^{\mathrm{b}}$ & $19.89^{\mathrm{a}}$ & 7.10 \\
\hline & SEM & 0.11 & 22.00 & 5.65 & 1.30 & 0.65 \\
\hline & $\mathrm{p}$-value & 0.044 & 0.392 & 0.013 & 0.042 & 0.337 \\
\hline \multirow[t]{5}{*}{ LS } & Early & 1.78 & 732.00 & $36.10^{\mathrm{a}}$ & $16.86^{\mathrm{c}}$ & 6.90 \\
\hline & Mid & 1.96 & 765.00 & $32.30^{\mathrm{b}}$ & $19.69^{b}$ & 7.30 \\
\hline & Late & 2.18 & 755.00 & $28.00^{c}$ & $21.10^{\mathrm{a}}$ & 7.24 \\
\hline & SEM & 0.45 & 38.45 & 3.14 & 0.26 & 1.50 \\
\hline & $\mathrm{p}$-value & 0.710 & 0.383 & 0.025 & 0.046 & 0.061 \\
\hline Parity* LS & $\mathrm{p}$-value & 0.000 & 0.072 & 0.041 & 0.016 & 0.340 \\
\hline
\end{tabular}

Note: $\mathrm{LS}=$ Lactation stage; $\mathrm{SCC}=$ somatic cell count; $\mathrm{CCT}=$ cheese clotting time; $\mathrm{CY}=$ cheese yield; $\mathrm{WV}=$ whey volume; $\mathrm{WpH}=$ whey $\mathrm{pH} ; \mathrm{SEM}=\mathrm{Standard}$ error of means. Means in the same column with different superscripts differ significantly $(\mathrm{p}<0.05)$.

Table 4. Interaction between parity and lactation stage on somatic cell count and cheese related properties of West African Dwarf goat milk

\begin{tabular}{|c|c|c|c|c|c|c|c|c|c|}
\hline \multirow{3}{*}{ Parity } & \multicolumn{9}{|c|}{ Lactation stage } \\
\hline & \multicolumn{3}{|c|}{ SCC $\left(\times 10^{5}\right.$ cells $\left./ \mathrm{mL}\right)$} & \multicolumn{3}{|c|}{$\mathrm{CY}(\mathrm{g})$} & \multicolumn{3}{|c|}{$\mathrm{WV}(\mathrm{mL})$} \\
\hline & Early & Mid & Late & Early & Mid & Late & Early & Mid & Late \\
\hline $1^{\text {st }}$ & $2.02^{\mathrm{a}}$ & $1.82^{c}$ & $1.19^{\mathrm{d}}$ & $16.95^{\mathrm{d}}$ & $17.21^{\mathrm{c}}$ & $20.85^{\mathrm{ab}}$ & $67.50^{\mathrm{a}}$ & $59.00^{\mathrm{b}}$ & $52.50^{c}$ \\
\hline $2^{\text {nd }}$ & $1.74^{c}$ & $1.80^{c}$ & $1.92^{\mathrm{c}}$ & $17.40^{c}$ & $21.04^{\mathrm{ab}}$ & $21.74^{\mathrm{a}}$ & $62.20^{\mathrm{a}}$ & $57.50^{\mathrm{b}}$ & $49.50^{\mathrm{d}}$ \\
\hline $3^{\text {rd }}$ & $1.70^{c}$ & $2.17^{\mathrm{a}}$ & $2.20^{\mathrm{a}}$ & $18.98^{\mathrm{b}}$ & $20.79^{\mathrm{ab}}$ & $21.95^{\mathrm{a}}$ & $59.30^{\mathrm{ab}}$ & $54.00^{\text {bc }}$ & $44.00^{\mathrm{d}}$ \\
\hline
\end{tabular}

Note: SCC= somatic cell count; $\mathrm{CY}$ cheese yield; $\mathrm{WV}=$ whey volume; Means in the same column and row for each of the dependent variables (SCC, $\mathrm{CY}$ and WV) with different superscripts differ significantly $(\mathrm{p}<0.05)$. 
Table 5. Correlation between somatic cell count and cheese variables of West African Dwarf goat milk

\begin{tabular}{ccccccc}
\hline & LS & PRT & SCC & CCT & CY & WV \\
\hline \multirow{2}{*}{ PRT } & $0.000 ;$ & & & & & \\
& 1.000 & & & & & \\
SCC & $0.932^{*} ;$ & $0.105 ;$ & & & & \\
& 0.000 & 0.602 & & & & \\
CCT & $-0.056 ;$ & $0.224 ;$ & $0.036 ;$ & & & \\
& 0.781 & 0.261 & 0.857 & & & \\
CY & $0.972^{*} ;$ & $0.035 ;$ & $0.901^{*} ;$ & $0.047 ;$ & & \\
& 0.000 & 0.861 & 0.000 & 0.816 & & \\
WV & $-0.986^{*} ;$ & $-0.010 ;$ & $-0.908^{*} ;$ & $0.060 ;$ & $-0.969^{*} ;$ & \\
& 0.000 & 0.961 & 0.000 & 0.766 & 0.000 & \\
WpH & $0.099 ;$ & $0.308 ;$ & $0.125 ;$ & $-0.064 ;$ & $0.086 ;$ & $-0.068 ;$ \\
& 0.623 & 0.117 & 0.533 & 0.751 & 0.671 & 0.735 \\
\hline
\end{tabular}

Note: PRT= Parity; LS= Lactation stage; $\mathrm{SCC}=$ somatic cell count; $\mathrm{CCT}=$ cheese clotting time; $\mathrm{CY}=$ cheese yield; $\mathrm{WV}=$ whey volume; $\mathrm{WpH}=$ whey $\mathrm{pH} ;{ }^{*}=$ indicates the correlation coefficient is significant $(p<0.05)$. Upper and lower values in each cell represent correlation coefficient and p-value respectively.

and milk somatic cell count of animals (Rupp et al., 2019). Similarly, unavoidable mammary epithelial debris is known to constitute to increase in SCC of milk (Li et al., 2016). Thus, SCC is a multifactorial parameter but may be conceptualized to be more affected by the intrinsic factor, particularly when the external factors are stabilized, as in the case of the present study. The similar SCC observed between the early and mid-lactation stage in the $2^{\text {nd }}$ parity aligns with Santoshi et al. (2018), who reported a fairly constant SCC for cows after the $7^{\text {th }}$ day post-partum. Comparative analysis of SCC based on parity by some authors showed a progressive increase in SCC values from young and primiparous mammals to multiparous class (Geneurova et al., 1993). This was claimed to have resulted from higher immunity of the mammary gland in the primiparous than multiparous animals (Alcindo et al., 2016). Increased milking exposure, which normally increases with age or parity, leads to physical damage of the epithelial tissues of the mammary gland and thereby results in longer infection and higher SCC often recorded in older animals (Alhussien \& Dang, 2017). Laevens et al. (1993), in another report, observed no difference between cows in the $3^{\text {rd }}$ and the $1^{\text {st }}$ parity compared to the $1^{\text {st }}$ and the $2^{\text {nd }}$ parities, which exhibited significantly different SCC. The non-uniform trend of SCC in each of the parity as lactation progresses may imply that non-infectious factors such as parity affect milk SCC of WAD goats differently from the cow (Jimenez-Granado, 2014). According to Alhussien \& Dang (2018), SCC is an admixture of milk-producing cell and immune cells and may be influenced by stress, environmental conditions, management practices, and even parity and stage of lactation. Thus, the non-uniform trend observed in this study should not be unexpected as those multifactorial influences may exert different effects on the goats. A report by some other authors (Goetsch et al., 2011; Jimenez-Granado et al., 2014) also concluded that the SCC is higher towards the end of lactation. This partly complies with the observations for the $3^{\text {rd }}$ parity does where a comparatively higher SCC was obtained after the early lactation stage. A significant parity effect on SCC indicated that a higher milk SCC is associated with multiple parities in WAD goats. According to Sharma et al. (2017), a comparatively lower SCC in younger goats may be due to their low milk-producing ability which was not captured in the present study.

The non-significant main effect of lactation stage on SCC in the current study contradicts the reports that SCC usually increases with the stage of lactation in goats (Jimenez-Granado et al., 2014; Pleguezuelos, 2015). However, the observation in the current study implies parity uncovers the effect of the lactation stage on the magnitude of SCC in WAD goat milk. The report by Orman et al. (2011), which indicates that the cellular concentration of goat milk is usually high towards the end of lactation, making it impossible to distinguish between uninfected and healthy glands through SCC is also not validated. Some authors (Dusabimana et al., 2012) also explained that higher SCC might be obtained during the late stages of lactation due to a dilution effect, which is not at pal with the current study. An increasing and significant trend of SCC reported by Jimenez-Granado (2014) as lactation progresses in goats also contradicts the current study. This may result from the range (200,000-500,000 cells) obtained by the authors, which was higher than the observation in the current study, which falls within 178,000 and 218,000 SCC. These authors also indicated a higher range of SCC with an increasing level of parity. Although the range in the current study was lower than the threshold of $1.0 \times 10^{6}$ (Li et al., 2014) for goat milk, the breed effect on SCC can also not be overlooked as earlier reported by (JimenezGranado et al., 2014).

The significant parity effect on the milk SCC of the goats in the present study corroborates the findings on the goat (Rota et al., 1993) and cattle (Saravanan et al., 2015; Gonçalves et al., 2018), which concluded that milk of primiparous species had lower SCC as compared to multiparous counterparts. Although Sheldrake et al. (1983) reported a significantly descending SCC as parity increases, this contradicts the present study in which the goats' milk in the $3^{\text {rd }}$ parity had a comparatively higher SCC than both the $1^{\text {st }}$ and the $2^{\text {nd }}$ parity goats which had comparable SCC. This result agrees with the findings of Orman et al. (2011), which indicates that the milk SCC of multiparous Turkish Saanen goats is comparatively higher than that of primiparous counterparts under similar conditions. Zeng \& Escobar (1995) also observed no significant difference in the milk SCC of goats of different parities.

A report by some authors (Abd El-Gawad \& Ahmed, 2011; Noutfia et al., 2014; Vacca et al., 2018a) asserted that CY tends to drop when the milk used is collected at the late lactation stage. This contradicts to the current study in which cheese yield increases as lactation progresses and could imply an increasing milk fat and protein trends as lactation advances (Garcia et al., 2014). Although the current study does not focus on milk composition, some earlier reports signified breed effect as well as non-uniform variation in fat and protein content of goat milk as lactation progresses. For instance, Idamokoro et al. (2017) described in their 
reports that Boer and Non-descript goats had a stable milk protein from the beginning to the end of lactation, while Mahmoud et al. (2014) asserted that the peak period for milk fat in Damascus goat was during the late stage of lactation. This may indicate that the milk fat of WAD goat follows the trend reported by the latter researchers. Similarly, the report by Jóźwik et al. (2012) on medium-yielding cows indicated a significantly lower milk fat and protein content at the early stage of lactation compared to the late stage. Thus, the result on $\mathrm{CY}$ in the current study corroborates the findings of Pazzola et al. (2019), which reported high milk fat and protein as a major cursor for improvement in cheese yield. The CY range in the present study $(16.89 \%-21.78 \%)$ was generally higher than what was reported (Vacca et al., 2018a) for some other goat breeds wherein rennet enzyme was used as the curdling milk agent. The cheese production method (whether or not the milk is subjected to pasteurization before curdling or addition of acidifier prior to coagulation) and type of coagulant employed may account for this difference.

Similarly, differences in the genetic makeup of the goat breed from which the milk is collected could also be the reason for the higher range of CY (Vacca et al., 2018b). The earlier report by Williams et al. (2012) asserted that WAD goat milk is exceptionally high in fat, and some other nutrients may also substantiate the high CY in the present study. Although not measured in the milk of individual goats, casein differences in the milk may also account for the variation in the cheese yield across parity and even the higher $\mathrm{CY}$ in the current study (Pazzola et al., 2019). A disproportionate level of casein $1,2 \mathrm{~K}$, and $\beta$ was earlier reported as a common phenomenon in goats and may also account for the exhibition of genetic polymorphism (Ballabio et al., 2011; Palmeri et al., 2014), which ensues great implication on cheese-making properties even within individuals (Pazzola et al., 2019).

Coagulating time for sheep milk in the cheesemaking process was influenced mainly by physicochemical properties of the milk (Park et al., 2007). Goat milk may, however, exhibit similar characteristics with this observation. The non-significant CCT in the current study could imply that the compositions of the goat milk in the current study are not significantly dissimilar irrespective of parity or lactation stage and may be due to the similar nutrition fed to the does. An earlier report by Ariza et al. (2019) also indicated that lactating animals fed different nutrition had significantly different milk compositions. Similarly, a report by Paschino et al. (2020) affirms that coagulant characteristics majorly account for the curdling rate in cheese production. Thus, non-significant cheese curdling duration (CCT) for the milk from different parities and stages of lactation could also be ascribed essentially to the similarities in coagulant properties (Soodam et al., 2015). Findings by some authors (Amira et al., 2017) also confirm that clotting time decreases when enzyme concentration is increased because of a higher level of proteolysis of kcasein. However, the coagulating time recorded in the present study (12-12.75 mins.) was slightly lower than 13 minutes reported as the average time for goat milk coagulation by Pazzola (2019) using rennet enzyme under laboratory conditions. This difference could result from variation in breed and properties of inoculant and that of milk properties (Bittante et al., 2013).

A positive and significant relationship observed between SCC and CY contradicts the reports by Silva et al. (2012) and Franceschi et al. (2020), who asserted that milk with high SCC is associated with loss of protein and consequential reduction in the CY. However, this may suggest that variation exists in the upper limit of SCC that could be impactful on the CY. Caravaca et al. (2012) also reported that the casein which normally aids increase in CY is usually attacked by the enzyme (proteases) for SCC and therefore recommend that milk should be low in SCC. A significant relationship observed between $\mathrm{CY}$ and lactation stage corroborates Abd El-Gawad \& Ahmed (2011), who substantiated that higher milk casein and fat at late laction stage accompanies higher $\mathrm{CY}$ at this stage than the $\mathrm{CY}$ at an early stage. The negative relationship between $\mathrm{WV}$ and $C Y$, which indicates that the more the CY, the lower the WV and vice versa, is suggestive of certain milk composition as a precursor for the increase in CY (Getaneh et al., 2012; Pazzola, 2019). This study asserts that the milk of WAD goats has acceptable SCC, which is more influenced by parity than the lactation stage. At the same time, its cheese yield is comparable with that of other conventional dairy goats and supports higher cheese, particularly when the goats are milked at the mid and late stages of lactation.

\section{CONCLUSION}

It was concluded that somatic cell count and cheese characteristic of WAD goat milk is more dependent on the lactation stage than parity. Milk of WAD goat has a relatively lower SCC and thus indicates its safety and reliability for human consumption. The milk collected from the mid to late lactation stage yields more cheese and could provide added advantage to WAD goat farmers who keep the goat for only meat purposes.

\section{CONFLICT OF INTEREST}

A research team comprising the entire authors of this article was granted Institution Based Research Grant funded by Tertiary Education Trust Fund (Nigeria). The authors hereby declare that there exists no potential conflict, be it personal, financial, cultural, or whatsoever, with respect to the objectivity of the manuscript. The authors have agreed to publish this article in its present form, and the manuscript has not been presented or accepted for publication in any other research outlets.

\section{ACKNOWLEDGEMENT}

The authors appreciate the Tertiary Education Trust Fund (Nigeria) for providing the grant to carry out the research. 


\section{REFERENCES}

Abd El-Gawad, M. A. M. \& N. S. Ahmed. 2011. Cheese yield as affected by some parameters: a review. Acta Sci. Pol. Technol. Aliment. 10:131-163.

Abdul-Rahman, I. I. 2017. Reproductive performance of West African Dwarf goats under guinea savannah conditions. Ghana Journal of Science, Technology and Development 5:35-42.

Abeykoon, C. D., R. M. C. Rathnayake, M. Johansson, G. L. L. P. Silva, C. S. Rhandheera, A. Lundh, \& J. K. Vidanarachechi. 2016. Milk coagulation properties and milk protein genetic variants of three cattle breeds/types in Sri Lanka. Procedia Food Sci. 6:348-351. https://doi. org/10.1016/j.profoo.2016.02.070

Alcindo, J. F., G. I. Braga, L. C. N. Mendes, M. Marinho, F. L. F. Feitosa. 2016. Physical, laboratory, and microbiological parameters of mammary gland secretions in postpartum does. Semin. Cienc. Agrar. 37:785-796. https://doi. org/10.5433/1679-0359.2016v37n2p785

Alhussien, M. N. \& A. K. Dang. 2017. Integrated effect of seasons and lactation stages on the plasma inflammatory cytokines, function and receptor expression of milk neutrophils in Sahiwal (Bos indicus) cows. Vet. Immunol. Immunopathol. 191:14-21. https://doi.org/10.1016/j. vetimm.2017.07.010

Alhussien, M. N. \& A. K. Dang. 2018. Milk somatic cell count, factors influencing their release, future prospect and particular utility in dairy animals: an overview. Vet. World. 11:562-577. https://doi.org/10.14202/vetworld.2018.562-577

Amira, A. B., S. Besbes, H. Attia, \& C. Blecker. 2017. Milkclotting properties of plant rennets and their enzymatic, rheological, and sensory role in cheese making: A review, Int. J. Food Prop. 20 (sup1):76-93. https://doi.org/10.1080/1 0942912.2017.1289959

Anusha, R., M. K. Singh, \& O. S. Bindhu. 2014. Characterisation of potential milk coagulants from Calotropis gigantea plant parts and their hydrolytic pattern of bovine casein. Eur. Food Res. Technol. 238: 997-1006. https://doi.org/10.1007/ s00217-014-2177-0

Ariza, J. M., T. Meignan, A. Madouasse, F. Beaudeau, \& N. Bareille. 2019. Effects on milk quantity and composition associated with extruded linseed supplementation to dairy cow diets. Sci. Rep. 9:17563. https://doi.org/10.1038/ s41598-019-54193-Z

Ballabio, C., S. Chessa, D. Rignanese, C. Gigliotti, G. Pagnacco, L. Terracciano, A. Fiocchi, P. Restani, \& A. M. Caroli. 2011. Goat milk allergenicity as a function of $\alpha \mathrm{s}_{1}$-casein genetic polymorphism. J. Dairy Sci. 94:998-1004. https://doi. org/10.3168/jds.2010-3545

Bittante, G., C. Cipolat-Gotet, \& A. Cecchinato. 2013. Genetic parameters of different measures of cheese yield and milk nutrient recovery from an individual model cheese- manufacturing process. J. Dairy Sci. 19:7966-7979. https://doi. org/10.3168/jds.2012-6517

Bittante, G., N. Cologna, A. Cecchinato, M. De Marchi, M. Penazza, \& F. Tiezi. 2011. Monitoring of sensory attributes of used in the quality payment system Trentingrana cheese, J. Dairy Sci. 94:5699 -5709. https://doi.org/10.3168/ jds.2011-4319

Caravaca, F., J. L Ares, J. Carrizosa, B. Urrutia, F. Baena, J. Jordana, B. Badaoui, A. Sànchez, A. Angiolillo, M. Amills, \& J. M. Serradilla. 2012. Effects of $\alpha$ s1-casein (CSN1S1) and $\kappa$-casein (CSN3) genotypes on milk coagulation properties in Murciano-Granadina goats. J. Dairy Res. 78:32-7. https://doi.org/10.1017/S002202991000083X

Chen, S. X., J. S. Wang, J. A S. Van-Kessel, F. Z. Ren, \& S. S. Zeng. 2010. Effect of somatic cell count in goat milk on yield, sensory quality, and fatty acid profile of semisoft cheese. J. Dairy Sci. 93:1345-1354. https://doi.org/10.3168/ jds.2009-2366

Chiejina, S. N. \& J. M. Behnke. 2011. The unique resistance and resilience of Nigerian West African Dwarf goats to gastrointestinal nematode infections. Parasit Vectors. 4:12. https://doi.org/10.1186/1756-3305-4-12

Cipolat-Gotet, C., A. Cecchinato, M. De Marchi, M. Penasa, \& G. Bittante. 2012. Comparison between mechanical and near infrared optical methods of assessing coagulation properties of bovine milk. J. Dairy Sci. 95:450-454. https:// doi.org/10.3168/jds.2012-5551

Clark, S. \& M. B. Mora-García. 2017. A 100-Year Review: Advances in goat milk research. J. Dairy Sci. 100:1002610044. https://doi.org/10.3168/jds.2017-13287

Dubey, V. K. \& M. V. Jagannadham. 2003. Procerain, a stable cysteine protease from the latex of Calotropis procera. Phytochemistry 62:1057-71. https://doi.org/10.1016/ S0031-9422(02)00676-3

Dusabimana, S., S. S. Layek, K. Behera, T. K. Mohanty, A. Kumaresan, A. Manimaran, A. K. Dang, \& S. Prasad. 2012. Effects of parity, season, stage of lactation, and milk yield on milk somatic cell count, $\mathrm{pH}$ and electrical conductivity in crossbred cows reared under subtropical climatic conditions. Milchwissenschaft 67:362-365.

Economic Confidential. 2019. Forex restriction: Milk imports to gulp N1.23trn annually. Economic confidential, 09:24. https://economicconfidential.com/2019/09/ milk-imports-gulp-n1-23trn-annually/

FAO. 2018. Livestock and Livelihood spotlight: Nigeria cattle and poultry system. Food and Agriculture Organization of the United Nations, Rome, Italy.

FAO. 2019. The Future of Livestock in Nigeria: Opportunity and Challenges in The Face of Uncertainty, Food and Agriculture Organization of the United Nations, Rome, Italy.

FAOSTAT. 2018. Corporate Statistical Data Base on Live animals' data. FAO, Rome, Italy.

Franceschi, P., M. Faccia, M. Malacarne, P. Formaggioni, \& A. Summer. 2020. Quantification of cheese yield reduction in manufacturing Parmigiano Reggiano from milk with noncompliant somatic cells count. Foods 9:1-10. https://doi. org/10.3390/foods 9020212

Garcia, V., S., Rovira, K. Boutoial, \& M. B. Lopez. 2014. Improvement in goat milk and quality: A review. Small Rumin. Res. 121:51-57. https://doi.org/10.1016/j. smallrumres.2013.12.034

Geneurova, V., O. Hanns, B. Gabriel, \& I. Zvackova. 1993. Somatic cell counts of milk in relation to production factors. Zivocisna Vyroba 38:359-367.

Getaneh, G., A. Mebrat, A. Wubie, \& H. Kendie. 2012. Review of goat milk composition and its nutritive value. J. Nutr. Health Sci. 3:401. https://doi.org/10.15744/2393-9060.3.401

Goetsch, A. L., S. S. Zeng, \& T. A. Gipson. 2011. Factors affecting goat milk production and quality. Small Rumin. Res. 101:5563. https://doi.org/10.1016/j.smallrumres.2011.09.025

Gonçalves, J. L., R. I. Cue, B. G. Botaro, J. A. Horst, A. A. Valloto, \& M. V. Santos. 2018. Milk losses associated with somatic cell counts by parity and stage of lactation. J. Dairy Sci. 101:4357-4366. https://doi.org/10.3168/jds.2017-13286

Hurst, J. 2014. Dairy goats: Milking the sanitary ways. Guide Sheet, Cooperative Extension. Lincoln University, New Zealand.

Idamokoro, E. M., V. Muchenje, \& P. J. Masika. 2017. Yield and milk composition at different stages of lactation from a small herd of Nguni, Boer, and Non-Descript goats raised in an extensive production system, Sustainability, 9:1000. https://doi.org/10.3390/su9061000

International Dairy Federation. 2011. The world dairy situation, Bulletin 451/2011. International Dairy Federation, Brussels, Belgium. 
Jimenez-Granado, R., M. Sanchez-Rodriguez, C. Arce, \& V. Rodriguez-Estevez. 2014. Factors affecting somatic cell count in dairy goats: a review. Span. J. Agric. Res. 12:133150. https://doi.org/10.5424/sjar/2014121-3803

Jóźwik, A., N. Strzałkowska, E. Bagnicka, W. Grzybek, J. Krzyżewski, E. Poławska, A. Kołataj, \& J. O. Horbańczuk. 2012. Relationship between milk yield, stage of lactation, and some blood serum metabolic parameters of dairy cows. Czech J. Anim. Sci. 57:353-360. https://doi. org/10.17221/6270-CJAS

Laevens, H., H. Deluyker, Y. H. Schukken, L. De Meulemeester, R. Vandermeersch, E, De Muelenaere, \& A. De Kruif. 1993. Influence of parity and stage of lactation on the somatic cell count in bacteriologically negative dairy cows. J. Dairy Sci. 80:3219-3226. https://doi.org/10.3168/jds. S0022-0302(97)76295-7

Li, H., H. Zheng, L. Li, X. Shen, W. Zang, \& Y. Sun. 2016. The effects of matrix Metalloproteinase- 9 on dairy goat mastitis and cell survival of goat mammary epithelial Cells 11(8): e0160989. https://doi.org/10.1371/journal.pone.0160989

Li, N., R. Richoux, M Boutinaud, P. Martin, \& V. Gagnaire. 2014. Role of somatic cells on dairy processes and products: A review. Dairy Sci. Technol. 94:517-538. https://doi. org/10.1007/s13594-014-0176-3

Mahmoud, N. M. A., I. E. M. El Zubeir, \& A. A. Fadlelmoula. 2014. Effect of stage of lactation on milk yield and composition of first kidder Damascus does in the Sudan. J. Anim. Prod. Adv. 4:355-362

MINITAB. 2013. Minitab Statistical Software, Release 14 for Windows. State College, Pennsylvania.

NRC. 2007. Nutrient Requirements of Small ruminants. National Academy of Sciences, Washington, DC.

Noutfia, Y., S. Zantar, M. Ibnelbachyr, S. Abdelouahab, \& I. Ounas. 2014. Effect of stage of lactation on the physical and chemical composition of Drâa goat milk. Afr. J. Food Agric. Nutr. Dev. 14:4.

Orman, A., A. Günay, F. Balci, \& M. Koyuncu. 2011. Monitoring of somatic cell count variations during lactation in primiparous and multiparous Turkish Saanen goats (Capra hircus). Turk .J. Vet. Anim. Sci. 35:169-175. https://doi. org/10.3906/vet-1002-253

Palmeri, M., S. Mastrangelo, M. T. Sardina, \& B. Portolano. 2014. Genetic variability at $\alpha$ s2-casein gene in Girgentana dairy goat breed. Ital. J. Anim. Sci. 13:116-118. https://doi. org/10.4081/ijas.2014.2997

Park, Y. W., M. Juarez, M. Ramos, \& G. F. W. Haenlein. 2007. Physico-chemical characteristics of sheep and goat milk. Small Rumin. Res. 68:88-113. https://doi.org/10.1016/j. smallrumres.2006.09.013

Paschino, P., G. Stocco, M. L. Dettori, M. Pazzola, M. L. Marongiu, C. E. Pilo, C. Cipolat-Gotet, \& G. M. Vacca. 2020. Characterization of milk composition, coagulation and cheese making ability of goats reared in extensive farms. J. Dairy Sci. 103: 5830-5843. https://doi.org/10.3168/ jds.2019-17805

Pazzola, M. 2019. Coagulant traits of sheep and goat milk. Animals 9:540. https://doi.org/10.3390/ani9080540

Pazzola, M., G. Stocco, M. L. Detorri, G. Bittante, \& G. Vacca. 2019. Effect of goat milk composition on cheesemaking traits and daily cheese production. J. Dairy Sci. 102:1-9. https://doi.org/10.3168/jds.2018-15397

Persson, Y. \& I. Olofsson. 2011. Direct and indirect measurement of somatic cell count as indicator of intramammary infection in dairy goats. Acta Vet. Scandin. 53:1-5. https:// doi.org/10.1186/1751-0147-53-15

Petzer, I., J. Karzis, E.F. Donkin, E. C. Webb, \& E. M. C. Etter. 2017. Somatic cell count thresholds in composite and quarter milk samples as indicator of bovine intramammary infection status. Onderstepoort J. Vet. Res. 84:a1269. https:// doi.org/10.4102/ojvr.v84i1.1269

Pleguezuelos, F. J., L. F. De La Fuente, \& C. Gonzalo. 2015 Variation in milk yield, contents and incomes according to somatic cell count in a large dairy goat population. J. Adv. Dairy Res. 3:1000145.

Rota, A. M., C. Gonzalo, P. L. Rodriguez, A. I. Rojas, L. Martin, \& J. J. Tovar. 1993. Effects of stage of lactation and parity on somatic cell counts in milk of Verata goats and algebraic models of their lactation curve. Small Rumin. Res. 12:211-219. https://doi.org/10.1016/0921-4488(93)90085-V

Rupp, R., C. Huau, H. Caillat T. Fassier, F. Bouvier, E. Pampouille, V. Clément, I. Palhière, H Larroque,, G. Tosser-Klopp, P. Jacquiet, \& P. Rainard. 2019. Divergent selection on milk somatic cell count in goats improves udder health and milk quality with no effect on nematode resistance. J. Dairy Sci. 102:5242-5253. https://doi. org/10.3168/jds.2018-15664

Santoshi, P., P. S. Oberoi, M. N. Alhussien, \& A. K. Dang. 2018. Combined effect of trisodium citrate and vitamin E supplementation during the transition period on body weight and other production parameters in Sahiwal cows. Ind. J. Dairy Sci. 71:78-83.

Sa'nchez-Macı'as, D., I. Moreno-Indias, S. A. lvarez, M. Clevelan, N. Castro, A. Argu"ello, \& M. R. Fresno. 2012. Sensory analysis of full-, reduced- and low-fat cheese elaborated with raw goat milk. J. Appl. Anim. Res. 40:124-132. https://doi.org/10.1080/09712119.2011.633880

Saravanan, R., D. N. Das, S. De, \& S. Panneerselvam. 2015. Effect of season and parity on somatic cell count across zebu and crossbred cattle population. Indian J. Anim. Res. 49:383-387. https://doi.org/10.5958/0976-0555.2015.00127.2

Sharma, T., P. K. Das, R. R. Ghosh, D. Banerjee, \& J. Mukherjee. 2017. Association between udder morphology and in-vitro activity of milk leukocytes in high yielding crossbred cows. Vet. World. 10:342-347. https://doi.org/10.14202/ vetworld.2017.342-347

Sharma, N. N., K. Singh, \& M. S. Bhadwal. 2011. Relationship of somatic cell count and mastitis: An overview. AsianAustralas. J. Anim. Sci. 24:429-438. https://doi.org/10.5713/ ajas.2011.10233

Sheldrake, R. F., R. J. T. Hoare, \& G. D. McGregor. 1983. Lactation stage, parity and infection affecting somatic cells, electrical conductivity and serum albumin in milk. J. Dairy Sci. 66:542-547. https://doi.org/10.3168/jds. S0022-0302(83)81823-2

Shivairo, R. S., J. Matofari, C. I. Muleke, P. K. Migwi, \& E. Lugairi. 2013. Factors influencing the somatic cell counts in goat milk in Kenya. Food Science and Quality Management 17: 47-53

Silva, N. M. A., L. P. F. Bastos, D. L. S. Oliveira, M. C. P. P. Oliveira, \& L. M. Fonseca. 2012. Influence of somatic cell count and total bacterial counts of raw milk in cheese yield using small-scale methodology. Arq Bras. Med. Vet. Zootec. 64:5. https://doi.org/10.1590/ S0102-09352012000500038

Soodam, K., L. Ong, I. B. Powell, S. E. Kentish, \& S. L. Gras. 2015. Effect of rennet on the composition, proteolysis and microstructure of reduced-fat Cheddar cheese during ripening. Dairy Sci. Technol. 95:665-686. https://doi. org/10.1007/s13594-015-0250-5

Souza, F. N., M. G. Blagitz, C. F. A. M. Penna, A. M. M. P. Della Libera, M. B. Heinemann, \& M. M. O. P. Cerqueira. 2012. Somatic cell count in small ruminants: Friend or foe?. Small Rumin. Res.107:65-75. https://doi.org/10.1016/j. smallrumres.2012.04.005

Taufik, E., G. Hildebrandt, J. N. Kleer, T. I. Wirjantoro, K. Kreausukon, K. H. Zessin, M. P. O. Baumann, \& F. H. 
Pasaribu. 2011. Microbiological quality of raw goat milk in Bogor, Indonesia. Med. Pet. 34:105-111. https://doi. org/10.5398/medpet.2011.34.2.105

Turkmen, N. 2017. The Nutritional Value and Health Benefits of Goat Milk Components. In: R. R. Watson, R. J. Collier, \& V. R. Preedy (Eds). Nutrients in Dairy and Their Implications on Health and Disease. Academic Press, Cambridge, Massachusetts. p. 441-449. https://doi.org/10.1016/ B978-0-12-809762-5.00035-8

Vacca, G. M., G. Stocco, M. L. Detorri, A. Summer, C. CipolatGohet, G. Bittante, \& M. Pazzola. 2018. Cheese yield, cheese making efficiency and daily production of six breeds of goat. J. Dairy Sci. 101:7817-7832. https://doi. org/10.3168/jds.2018-14450

Vacca, G. M., G. Stocco, M. L. Dettori, E. Pira, G. Bittante, \& M. Pazzola. 2018. Milk yield, quality and coagulation properties of six breeds of goats: Environmental and individual variability. J. Dairy Sci. 101:7236-72347. https://doi. org/10.3168/jds.2017-14111
Williams, T. J., I. J. James, M. R. Abdulateef, L. O. Onabegun, S. O. Jinadu, Y. O. Falade, F. T. Solola, O. O. Adewumi, \& O. E. Oke. 2012. Composition and specific gravity of milk of West African Dwarf sheep as affected by stage of lactation and parity. Niger. J. Anim. Prod. 39:2. https://doi. org/10.51791/njap.v39i2.838

Williams, T. J., M. O., Ozoje, N. Okwelum, O. O. O. Adewumi, \& M. O. Abioja. 2019. Milk yield in West African Dwarf goats as influenced by coat colour, liveweight, week of lactation and udder circumference, Nigerian Journal of Animal Production. 46:325 - 332.

Yusuff, A. T. \& T. R. Fayeye. 2016. Effect of season \& genotype on haematological profile and parasitic susceptibility of two Nigerian goat breeds and their reciprocal crosses. NSUK Journal of Science and Technology 6:161-165.

Zeng, S. S. \& E. N. Escobar. 1995. Effect of breed and milking method on somatic cell count, standard plate count and composition of goat milk. Small Rumin. Res. 19:169-175. https://doi.org/10.1016/0921-4488(95)00744-X 